\title{
In Silico Identification and Characterization of Potential Drug Targets in Bovine Herpes Virus 4, Causing Bovine Mastitis
}

\author{
Mahantesh M. Kurjogi and Basappa B. Kaliwal \\ Department of Microbiology and Biotechnology, Karnatak University, Dharwad, Karnataka 580003, India \\ Correspondence should be addressed to Mahantesh M. Kurjogi; mahantesh.kurjogi@gmail.com
}

Received 15 May 2014; Revised 18 July 2014; Accepted 21 July 2014; Published 7 August 2014

Academic Editor: Brenda A. Wilson

Copyright ( 2014 M. M. Kurjogi and B. B. Kaliwal. This is an open access article distributed under the Creative Commons Attribution License, which permits unrestricted use, distribution, and reproduction in any medium, provided the original work is properly cited.

\begin{abstract}
The purpose of this study is to deal with aetiology causing bovine mastitis; bovine herpes virus is also responsible for causing bovine mastitis but studies on viruses have been neglected as historical mastitis research has concentrated only on bacterial pathogens. Therefore, present study aims to make an in silico identification and characterization of potential drug targets in bovine herpes virus 4 by computational methods using various bioinformatics tools. In the current investigation 5 proteins of BoHV 4 were found to be nonhomologous to the host Bos taurus; these nonhomology proteins were believed to be inevitable proteins of BoHV 4 as they were specific to the virus; however 378 proteins were homologous to the host protein. The in silico physicochemical characterization of 5 proteins of BoHV 4 indicated that all the proteins of the virus were having more or less similar characteristics. Perhaps the knowledge of the present study may help in drug discovery which have high affinity to target site. Possible drug discovery to manage bovine mastitis with a help of bioinformatics tool is more significant and, specific and, reduces time and complications involved in clinical trials.
\end{abstract}

\section{Introduction}

Bovine mastitis is generally considered to be of infectious nature leading to inflammation of one or more quarters of mammary gland and it is often affecting not only individual animal but the whole herd or at least several animals within the herd. If left untreated, the condition can lead to deterioration of animal welfare resulting in culling of affected cows or even death.

Mastitis-causing pathogens include bacteria and nonbacterial pathogens, like mycoplasmas, fungi, yeasts, and chlamydia $[1,2]$. These pathogens infect udder generally through ductus papillaris, which is the only opening of udder to the outside world. Despite intensive aetiological research, still around $20-35 \%$ of clinical cases of bovine mastitis have an unknown aetiology $[3,4]$. Wedderkopp did not note pathogens in 35\% of 6809 milk quarters in 3783 cows suffering from clinical mastitis [4]. The percentage of culture negative samples of both clinical and subclinical mastitis cases in the Netherlands has been determined to be approximately $25 \%$ [5]. An explanation for these high percentages of culture-negative samples might be a low concentration of udder pathogenic bacteria. Other pathogens such as mycoplasma, yeasts, and moulds are difficult to cultivate. But these agents cannot be the explanation for all culture negative milk samples from mastitis cows, as they are not a common udder pathogen $[6,7]$. Due to high percentages of unknown causes of mastitis, it is obvious to study the role of viruses in the aetiology of bovine mastitis in spite of the fact that viruses are generally considered not to play an important role.

Watts has identified 137 microbial species as causative agents of bovine mastitis, including agents involved in its pathogenesis [1]. However, viruses were not included. The reasons for this negligence could be manifold. Historically, mastitis research has concentrated on bacterial pathogens. In case of viral infections, signs of mastitis may not have been recognised because other clinical signs were more prominent. Subclinical mastitis cases are often not diagnosed and consequently their aetiology is not investigated. This may cause an underestimation of virus infections involved in bovine subclinical mastitis. Another reason might be that 
milk samples from mastitis cows are often not properly collected, treated, and stored for virological research, as this requires special care. The laboratory diagnosis of viral mastitis is laborious and expensive. Diagnostic tools, for example, susceptible cells, for detection of viruses are often not optimally used. These arguments might explain why it is difficult to estimate the importance of viral infection on aetiology of bovine mastitis and their economical impact. It is more serious in countries like India which is the highest milk producer in the world and requires an urgent attention and novel methods of intervention to control disease. In this context all the drugs selected for treatment of bovine mastitis against a particular infectious agent have to be screened through in silico study by using bioinformatics tools and will have to be notified through a database dedicated for this purpose which helps in identifying the high prevalence of bovine mastitis and its aetiology in a particular area.

Bovine herpes virus 4 is a member of family herpesviridae, subfamily gamma herpesviridae, belonging to order herpesvirales, and genes rhadinovirus. Virus has a wide host range which is known to infect different ruminant species like cattle, sheep, and goats $[8,9]$. BoHV4 needs dividing cells for effective virus replication as there is increase in viral DNA replication and protein expression at $S$ phase of the cell cycle. The main targets for viral replication are lymphoid organs, upper respiratory tract, and urogenital and balimentary tracts. The lymphoid organs and mononuclear blood cells are also possible primary sites of viral latency [10], and the nervous system was also suspected of being involved in persistence of virus [11].

Herpesviridae family has been isolated from cows with various clinical signs, including mammary pustular dermatitis [12] and chronic ulcerative mammary dermatitis [13]. A possible role of BoHV4 in bovine mastitis was supported by the fact that BoHV4 was isolated from the milk of cows with and further examined there was an ongoing BoHV4 infection in 4 of 10 herds at the same time as mastitis occurred [14]. The simultaneous intramammary and intranasal inoculation of lactating cows with BoHV4 did not result in clinical mastitis. However, subclinical mastitis was induced in 2 out of 4 inoculated lactating cows suggesting the possible role of BoHV4 in bovine mastitis [14].

During an epidemiological study, a positive association between the presence of BoHV4 antibodies in cows and incidence of bovine mastitis caused by Staphylococcus aureus was recorded [15]. This finding suggests that a previous BoHV4 infection promotes the development of mastitis especially caused by Staphylococcus aureus and in previous study we reported that $S$. aureus was the most predominant organism causing bovine mastitis in this part of the country [16]. The researchers from Canada reported that overall prevalence of antibodies against BoHV- 4 in the milk samples of 176 cows tested was $98.2 \%$ [17] and this is consistent with the previously reported high seroprevalence of 84 and $79 \%$ in 2 Dutch dairy herds [18].

All the above mentioned studies strongly suggest a role for BoHV4 in bovine mastitis. Although, BoHV4 probably does not appear to play an important role as primary udder pathogen in the aetiology of clinical mastitis, it may play a role in subclinical mastitis cases or in an indirect way. More research has to be warranted to establish a possible indirect role of BoHV4 infections in bovine mastitis. However virus is much more associated with chronic inflammations of the endometrium and bovine postpartum uterine disease and affects about $40 \%$ of animals [19]. Therefore, present study aims to make an in silico identification and characterization of potential drug targets in bovine herpes virus 4 by computational methods using various bioinformatics tools.

\section{Methodology}

2.1. Prediction of Target for Drug Discovery. All the proteins sequences belonging to BoHV4 were retrieved from http:// www.ncbi.nlm.nih.gov/protein/?term=txid10385[Organism: exp] on January 2013. The methodology used in present study for in silico identification of drug target in BoHV 4 were as per Zhang et al. [20] and Aravind et al. [21] with little modifications. The proteins which do not appear in host Bos taurus but present in the BoHV 4 have been considered as proteins unique to the bovine herpes virus 4 .

All the corresponding amino acid sequences of proteins involved in the synthesis of viral particle were retrieved and subjected to a Basic Local Alignment Search Tool (BLAST) search against the nonredundant database. The search was restricted to proteins from Bos taurus through an option available in BLAST program; this analysis was carried out for detection of nonhomologous proteins in host, proteins which are absent in host Bos taurus but present in BoHV 4 were picked out as potential drug targets. All the nonhomologous proteins were believed to be essential proteins whose functions are indispensable for survival of BoHV 4.

2.2. Characterization of Nonhomology Protein. All the essential proteins amino acid sequences were characterized by using Peptide Statistic (PEPSTAT) program which is available online via European Molecular Biology Open Software Suite (EMBOSS) web server [22]. Proteins found to be nonhomologous to host protein were subjected to a tool from the web consists of a simple multiple steps process which works on Dayhoff statistics. DayhoffStat is the amino acid's molar percentage divided by Dayhoff statistic. The Dayhoff statistic is the amino acid's relative occurrence per 1000 aa normalised to 100 .

2.3. BLASTN Programs Search. The individual genes responsible for coding drug target proteins were screened using Basic Local Alignment Search Tool (BLASTn) against NCBI's nonredundant nucleotide database for pairwise alignment search of nucleotide sequence similarity that matches with query sequence within the existing nucleotide sequence database in the month of July, 2014.

\section{Results}

3.1. Prediction of Target for Drug Discovery. A total of 383 proteins of BoHV 4 were retrieved from the database out of which 5 proteins were found to be nonhomology protein 
TABLE 1: In silico characterization of nonhomologous proteins of Bovine herpes virus 4 searched against Bos taurus.

\begin{tabular}{|c|c|c|c|c|c|c|c|c|}
\hline Sl. No & Name of the protein & GI & Accession & Number of AA & Mol wt & Isoelectric point & $\mathrm{A} 280 \mathrm{mec}$ & ec values \\
\hline 1 & Hypothetical protein $\mathrm{pBo} 14$ & 13095654 & NP_076569.1 & 170 & 18173.30 & 4.0189 & 6400 & -19.0 \\
\hline 2 & Probable glycoprotein & 13095646 & NP_076561.1 & 449 & 51457.01 & 6.9723 & 43810 & 5.0 \\
\hline 3 & Tegument protein & 13095644 & NP_076559.1 & 256 & 29725.62 & 8.5335 & 31150 & 10.0 \\
\hline 4 & Glycoprotein M & 13095616 & NP_076531.1 & 369 & 43051.03 & 9.1096 & 74960 & 12.0 \\
\hline 5 & Capsid protein & 13095594 & NP_076509.1 & 515 & 57449.15 & 7.0111 & 42670 & 6.0 \\
\hline
\end{tabular}

to the host Bos taurus. The name of 5 proteins along with their gene identity number and accession numbers were represented in Table 1.

The present study indicates that very few proteins [5] present in BoHV4 were specific to virus; however rest of the proteins were homologous to host protein.

3.2. Characterization of Nonhomology Protein. The amino acid sequence of 5 specific proteins of BoHV 4 was subjected to PEPSTAT program which revealed the abundance of each amino acid in the protein and their molecular percent with respect to DayhoffStat.

The present in silico characterization study of 5 proteins showed that some similar characteristics were observed in all the proteins of BoHV4 that subjected to the PEPSTAT program. All the proteins molecular weight lies between 18$57 \mathrm{KDa}$ that is hypothetical protein, probable glycoprotein, tegument protein, glycoprotein $\mathrm{M}$ and capsid protein molecular weight was 18173.30, 51457.01, 29725.62, 43051.03 and 57449.15 , respectively. An average residue weight of hypothetical protein, probable glycoprotein, tegument protein, glycoprotein $\mathrm{M}$ and capsid protein was 106.902, 114.604, $116.116,116.669$ and 111.552, respectively. Isoelectric point of the proteins showed that all the proteins were basic in nature except hypothetical protein pBol4 which was acidic in nature. Molar extinction coefficient of hypothetical protein at A280 is 6400 , for tegument protein is 31150 , glycoprotein $M$ is 74960 , probable glycoprotein is 43810 and for capsid protein 42670 . Proline was found to be in highest number in hypothetical protein pBol4 and capsid protein whereas leucine was found to be highest in probable glycoprotein, tegument protein and glycoprotein $M$. Non polar amino acids were found to be in more numbers in the proteins of virus when compared with that of polar amino acids. In the present in silico study of characterization of nonhomology proteins showed that all the proteins were approximately similar in their some of the physicochemical properties.

3.3. BLASTN Programs Search. The screening of hypothetical protein $\mathrm{pBo} 14$ for pairwise alignment search reveled that only two sequences of bovine herpes virus 4 showed significant alignments to query sequence with similar function of coding hypothetical protein pBo14. But the screening of probable glycoprotein, tegument protein, glycoprotein $M$, and capsid protein indicated that only one sequence of BoHV4 showed significant alignment with query sequence and function of all the genes was found to code for hypothetical protein.

\section{Discussion}

4.1. Prediction of Target for the Drug Discovery. The in silico based approach involves a series of screening proteins that can be used as potential drug targets and vaccine candidates [23]. In the present study 5 proteins of BoHV 4 were found to be nonhomology to the host Bos taurus these nonhomology proteins were believed to be inevitable proteins of BoHV4 as they were specific to virus, however 378 proteins were homology to the host protein. Tegument proteins are known to be involved in a variety of activities that promote virus infectivity, including shut-off of host protein synthesis [24, 25] or the induction of transcription of incoming genome in the nucleus [26]. Deletion of gene for tegument protein VP22 has a significant effect on replication of bovine herpes virus type 1 [27] and Marek's disease virus [28]. Mubarak with his co-workers demonstrated that deletion of a glycinerich epitope in the glycoprotein $\mathrm{E}$ ectodomain dramatically reduced BoHV-5 neurovirulence [29].

Several studies have shown that a novel glycoprotein designated $\mathrm{gL}$ is encoded by members of all herpes virus subgroups, including alpha, beta, and gamma herpes viruses, which is required for correct processing and transport of glycoprotein $\mathrm{H}$ [30-32]. The capsid and envelope play many roles in viral infection, including virus attachment to cells, entry into cells, release of capsid contents into the cells, and packaging of newly formed viral particles. The capsid and envelope are also responsible for transfer of the viral genetic material from one cell to another [33]. Using such in silico approach, novel targets have been identified successfully for various pathogens in different studies [34-39].

Although current investigation did not present any experiments to validate these 5 proteins as drug targets, it is evident from previous reports that these 5 non homology proteins are possible site for drug targets. Therefore, the present investigation believed that non homologous proteins of virus were best target for the drug design against viral bovine mastitis, However, the host Bos taurus remains unaffected as drugs will be target specific and more significant.

4.2. Characterization of Nonhomology Protein. The 3D structure of a protein is determined by sequence of amino acids along the polypeptide and the amino acids can be characterized by their physicochemical properties. For example some amino acids are polar and like water (hydrophilic amino acids) others are most happy when not in direct contact with water (hydrophobic amino acids). Hydrophobic amino acids 
are more frequently found buried within the proteins 3D structure while hydrophilic ones are more frequently found on the exposed surface of proteins. The amino acids also differ in size, charge, polarity, and a number of other properties. The similarity of two amino acids physiochemical properties has been found to be related to how often one finds one replaced with other in related protein structures [40].

One of the common character observed from present study suggest that number of aliphatic amino acids were more than aromatic amino acids in all the studied proteins of virus. Similarly Bhasme et al. reported in silico characterization of two proteins of S. saprophyticus which were non homology to the host [41]. Viral entry into cells is a multi-step process involving several glycoproteins and at least two cellular receptors [42]. Glycoprotein of alphaherpesviruses initiates these steps by binding to heparan sulfate proteoglycans on the cell surface. These receptor molecules are present on many cells, thus allowing adsorption of herpesviruses to a variety of different cell types [43]. This protein was expressed on the cell membrane of virus infected cells and was designated as glycoprotein G-2 [44]. Glycoprotein M forms a complex with glycoprotein $\mathrm{N}$ which is one of the most highly conserved of all herpesvirus glycoproteins and has been retained in a recognizable form over hundreds of millions of years of viral evolution [45-49]. A viral tegument or tegument, more commonly known as a viral matrix, is a cluster of proteins that lines the space between the envelope and nucleocapsid of all herpesviruses (http://www.uniprot.org/keywords/920). The tegument generally contains proteins that aid in viral DNA replication and evasion of immune response, typically with inhibition of signalling in the immune system and activation of interferons. The tegument is usually released shortly after infection into the cytoplasm. These proteins are usually formed within the late phase of viral infectious cycle, after viral genes have been replicated [50]. In the era of large genomics and proteomics prediction of promoters in the whole genome is crucial for drug discovery and gene therapy [51]. Similarly identification of drug targets in Bovine herpes virus plays a vital role in drug discovery against bovine mastitis.

4.3. BLASTN Programs Search. Beside the traditional drug which binds to target proteins, the genes responsible for coding drug target protein are found to be very specific and exclusive in their nature of producing crucial proteins of the virus. Therefore these genes are of significant interest in the field of antisense technology where the chemically synthesized oligonucleotide blocks the synthesis of inevitable viral proteins by binding to the mRNA. Hence mRNA of these genes will be a supplementary target for drugs of antisense technology.

\section{Conclusion}

In present study 5 proteins of BoHV 4 were found to be nonhomologous to the host Bos Taurus and were believed to be inevitable proteins of BoHV 4 as they were specific to the virus. In silico physicochemical characterization of these proteins indicated that all the proteins of the virus werehaving comparatively similar characteristics. Perhaps the knowledge of the present study made drugdiscovery easier which have high affinity to target site. Possible drug discovery to managebovine mastitis with a help of bioinformatics tool is more significant and specific and reduces time andcomplications involved in the clinical trials. Further investigations are needed to elucidatewhether BHV-4 is one of primary causative agents in bovine mastitis or whether the BHV-4 reactivation occurs due to primary bacterial insults. The studies conclude that the futurebioinformatics research holds tremendous hope for drug discovery of the bovine mastitis.

\section{Conflict of Interests}

The authors declare that there is no conflict of interests regarding the publication of this paper.

\section{Acknowledgments}

Authors are profusely thankful to the Department of Biotechnology (DBT), Ministry of Science and Technology, Government of India, New Delhi, for funding the Bioinformatics Infrastructure Facility Project (BT/BI/25/001/2006 VOL II date 05-03-2012) and Interdisciplinary Program for Life Science Project (BT/PR/4555/INF/22/126/2010 dated 30-092010) and P. G Departments of Biotechnology and Microbiology Karnatak University, Dharwad, for providing the facilities for pursuing the research work at the department.

\section{References}

[1] J. L. Watts, "Etiological agents of bovine mastitis," Veterinary Microbiology, vol. 16, no. 1, pp. 41-66, 1988.

[2] O. M. Radostits, D. C. Blood, and C. C. Gay, "Mastitis," in Veterinary Medicine, Bailliëre Tindal, London, UK, 1994.

[3] J. D. Miltenburg, D. de Lange, A. P. P. Crauwels et al., "Incidence of clinical mastitis in a random sample of dairy herds in the Southern Netherlands," Veterinary Record, vol. 139, no. 9, pp. 204-207, 1996.

[4] A. Wedderkopp, "Haemophilus somnus-unlikely to be a causative microbiological agent in bovine clinical mastitis in denmark," Acta Veterinaria Scandinavica, vol. 38, no. 2, pp. 193 195, 1997.

[5] H. W. Barkema, Y. H. Schukken, T. J. G. M. Lam et al., "Incidence of clinical mas titis in dairy herds grouped in three categories by bulk milk somatic cell count," Journal of Dairy Science, vol. 81, no. 2, pp. 411-419, 1998.

[6] H. Pfutzner, "Mastitiden: mycoplasma infection," in Euter-und Gesäugekrankheiten, K. Wendt, H. Bostedt, H. Mielke, and H. W. Fuchs, Eds., pp. 410-416, Gustav Fischer, Stuttgart, Germany, 1994.

[7] K. Wendt, "Mastitiden: hefen- und plizeinfectionen," in Euterund Gesäugekrankheiten, K. Wendt, H. Bostedt, H. Mielke, and H.-W. Fuchs, Eds., pp. 416-422, Gustav Fisher, 1994.

[8] E. VanOpdenbosch, G. Wellemans, L. A. A. Ooms, and A.-D. A. Y. Degryse, " $\mathrm{BHV}_{4}$ (bovine herpes virus 4) related disorders in Belgian cattle: a study of two problem herds," Veterinary Research Communications, vol. 12, no. 4-5, pp. 347-353, 1988. 
[9] M. A. Mahmoud and S. A. Ahmed, "Prevalence of bovine herpesvirus-1 in sheep and goats in Egypt," Global Veterinaria, vol. 3, no. 6, pp. 472-479, 2009.

[10] F. A. Osorio and D. E. Reed, "Experimental inoculation of cattle with bovine herpesvirus-4: evidence for a lymphoid-associated persistent infection," American Journal of Veterinary Research, vol. 44, no. 6, pp. 975-980, 1983.

[11] L. A. Krogman and J. P. McAdaragh, "Recrudescence of bovine herpesvirus-5 in experimentally infected calves," American Journal of Veterinary Research, vol. 43, no. 2, pp. 336-338, 1982.

[12] D. E. Reed, T. J. Langpap, and M. A. Anson, "Characterization of herpesviruses isolated from lactating dairy cows with mammary pustular dermatitis," American Journal of Veterinary Research, vol. 38, no. 10, pp. 1631-1634, 1977.

[13] S. Cavirani, G. Allegri, and C. F. Flammini, "Isolation of bovid herpesvirus-4 (BHV-4) from cows affected by chronic ulcerative mammary dermatitis," Estratto da Selezione Veterinaria, vol. 31, pp. 1251-1260, 1990.

[14] G. J. Wellenberg, W. H. M. van der Poel, T. J. K. van der Vorst et al., "Bovine herpesvirus 4 in bovine clinical mastitis," Veterinary Record, vol. 147, no. 8, pp. 222-225, 2000.

[15] R. N. Zadoks, H. G. Allore, H. W. Barkema et al., "Cowand quarter-level risk factors for Streptococcus uberis and Staphylococcus aureus mastitis," Journal of Dairy Science, vol. 84, no. 12, pp. 2649-2663, 2001.

[16] M. M. Kurjogi and B. B. Kaliwal, "Prevalence and antibiotic susceptibility of bacteria isolated from Bovine mastitis," Advances in Applied Science Research, vol. 2, no. 6, pp. 229-235, 2011.

[17] H. Ali, G. P. Keefe, and A. Cepica, "Bovine herp esvirus-4, a potential cause of mastitis in Canadian Dairy Cows," British Journal of Dairy Sciences, vol. 2, no. 3, pp. 31-34, 2011.

[18] R. N. Zadoks, H. G. Allore, H. W. Barkema et al., "Cowand quarter-level risk factors for Streptococcus uberis and Staphylococcus aureus mastitis," Journal of Dairy Science, vol. 84, no. 12, pp. 2649-2663, 2001.

[19] G. Gaetano Donofrio, A. Capocefalo, V. Franceschi, S. Price, S. Cavirani, and I. M. Sheldon, "The chemokine IL8 is upregulated in bovine endometrial stromal cells by the BoHV-4 IE2 gene product, ORF50/Rta: a step ahead toward a mechanism for BoHV-4 induced endometritis," Biology of Reproduction, vol. 83, no. 6, pp. 919-928, 2010.

[20] R. Zhang, H. Ou, and C. Zhang, "DEG: a database of essential genes," Nucleic Acids Research, vol. 32, pp. D271-D272, 2004.

[21] L. Aravind, D. D. Leipe, and E. V. Koonin, "Toprim-a conserved catalytic domain in type IA and II topoisomerases, DnaG-type primases, OLD family nucleases and RecR proteins," Nucleic Acids Research, vol. 26, no. 18, pp. 4205-4213, 1998.

[22] A. Labarga, S. Pilai, F. Valentin, M. Anderson, and R. Lopez, "Web services at EBI," EMBnetNews, vol. 11, no. 4, pp. 18-23, 2005.

[23] J. J. Georrge and V. Umrania, "In silico identification of putative drug targets in Klebsiella pneumonia MGH78578," Indian Journal of Biotechnology, vol. 10, no. 4, pp. 432-439, 2011.

[24] A. D. Kwong and N. Frenkel, "The herpes simplex virus virion host shutoff function," Journal of Virology, vol. 63, no. 11, pp. 4834-4839, 1989.

[25] C. A. Smibert, D. C. Johnson, and J. R. Smiley, "Identification and characterization of the virion-induced host shutoff product of herpes simplex virus gene UL41," Journal of General Virology, vol. 73, no. 2, pp. 467-470, 1992.
[26] P. O'Hare, "The virion transactivator of herpes simplex virus," Seminars in Virology, vol. 4, no. 3, pp. 145-155, 1993.

[27] X. Liang, B. Chow, Y. Li et al., "Characterization of bovine herpesvirus 1 UL49 homolog gene and product: bovine herpesvirus 1 UL49 homolog is dispensable for virus growth," Journal of Virology, vol. 69, no. 6, pp. 3863-3867, 1995.

[28] F. Dorange, B. K. Tischer, J. Vautherot, and N. Osterrieder, "Characterization of Marek's disease virus serotype 1 (MDV-1) deletion mutants that lack UL46 to UL49 genes: MDV-1 UL49, encoding VP22, is indispensable for virus growth," Journal of Virology, vol. 76, no. 4, pp. 1959-1970, 2002.

[29] A. Al-Mubarak, J. Simon, C. Coats, J. D. Okemba, M. D. Burton, and S. I. Chowdhury, "Glycoprotein E (gE) specified by bovine herpesvirus type 5 (BHV-5) enables trans-neuronal virus spread and neurovirulence without being a structural component of enveloped virions," Virology, vol. 365, no. 2, pp. 398-409, 2007.

[30] L. Hutchinson, H. Browne, V. Wargent et al., "A novel herpes simplex virus glycoprotein, gL, forms a complex with glycoprotein $\mathrm{H}(\mathrm{gH})$ and affects normal folding and surface expression of gH," Journal of Virology, vol. 66, no. 4, pp. 2240-2250, 1992.

[31] J. F. Kaye, U. A. Gompels, and A. C. Minson, "Glycoprotein H of human cytomegalovirus (HCMV) forms a stable complex with the HCMV UL115 gene product," Journal of General Virology, vol. 73, no. 10, pp. 2693-2698, 1992.

[32] D. X. Liu, U. A. Gompels, J. Nicholas, and C. Lelliott, "Identification and expression of the human herpesvirus 6 glycoprotein $\mathrm{H}$ and interaction with an accessory $40 \mathrm{~K}$ glycoprotein," Journal of General Virology, vol. 74, no. 9, pp. 1847-1857, 1993.

[33] W. Lucas and D. M. Knipe, Viral Capsids and Envelopes: Structure and Function, Encyclopedia of Life Sciences, Macmillan, 2002.

[34] A. Dutta, S. K. Singh, P. Ghosh, R. Mukherjee, S. Mitter, and D. Bandyopadhyay, "In silico identification of potential therapeutic targets in the human pathogen helicobacter pylori," In Silico Biology, vol. 6, no. 1-2, pp. 43-47, 2006.

[35] S. Singh, B. K. Malik, and D. K. Sharma, "Metabolic pathway analysis of $S$. pneumoniae: an in silico approach towards drugdesign," Journal of Bioinformatics and Computational Biology, vol. 5, no. 1, pp. 135-153, 2007.

[36] D. Barh and A. Kumar, "In silico identification of candidate drug and vaccine targets from various pathways in Neisseria gonorrhoeae," In Silico Biology, vol. 9, no. 4, pp. 225-231, 2009.

[37] B. Rathi, A. N. Sarangi, and N. Trvedi, "Genome subtraction for novel target definition in Salmonella typhi," Bioinformation, vol. 4, pp. 143-150, 2009.

[38] U. Amineni, D. Pradhan, and H. Marisetty, "In silico identification of common putative drug targets in Leptospira interrogans," Journal of Chemical Biology, vol. 3, no. 4, pp. 165-173, 2010.

[39] G. Koteswara Reddy, K. NagmalleshwaraRao, B. Phani Rama Krishna, and S. Arvind, "In silico identification of potential therapeutic targets in Clostridium botulinum by the approach subtractive genomics," International Journal of Bioinformatics Research, vol. 2, no. 2, pp. 12-16, 2010.

[40] E. Ingvar, J. Inge, and R. W. Taylor, Protein Bioinformatics: An Algorithmic Approach to Sequence and Structure Analysis, Wiley India, 2009.

[41] P. C. Bhasme, M. M. Kurjogi, R. D. Sanakal, R. B. Kaliwal, and B. B. Kaliwal, "In silico characterization of putative drug targets in Staphylococcus saprophyticus, causing bovine mastitis," Bioinformation, vol. 9, no. 7, pp. 339-344, 2013.

[42] T. C. Mettenleiter, "Initiation and spread of $\alpha$-herpesvirus infections," Trends in Microbiology, vol. 2, no. 1, pp. 2-4, 1994. 
[43] A. Karger, A. Saalmuller, F. Tufaro, B. W. Banfield, and T. C. Mettenleiter, "Cell surface proteoglycans are not essential for infection by pseudorabies virus," Journal of Virology, vol. 69, no. 6, pp. 3482-3489, 1995.

[44] B. Roizman, B. Norrild, C. Chan, and L. Pereira, "Identification and preliminary mapping with monoclonal antibodies of a herpes simplex virus 2 glycoprotein lacking a known type 1 counterpart," Virology, vol. 133, no. 1, pp. 242-247, 1984.

[45] A. Jöns, J. M. Dijkstra, and T. C. Mettenleiter, "Glycoproteins M and $\mathrm{N}$ of pseudorabies virus form a disulfide-linked complex," Journal of Virology, vol. 72, no. 1, pp. 550-557, 1998.

[46] S. Koyano, E. C. Mar, F. R. Stamey, and N. Inoue, "Glycoproteins $\mathrm{M}$ and $\mathrm{N}$ of human herpesvirus 8 form a complex and inhibit cell fusion," Journal of General Virology, vol. 84, no. 6, pp. 14851491, 2003.

[47] C. M. Lake, S. J. Molesworth, and L. M. Hutt-Fletcher, "The Epstein-Barr virus (EBV) gN homolog BLRF1 encodes a 15kilodalton glycoprotein that cannot be authentically processed unless it is coexpressed with the EBV gM homolog BBRF3," Journal of Virology, vol. 72, no. 7, pp. 5559-5564, 1998.

[48] M. Mach, B. Kropff, P. Dal Monte, and W. Britt, "Complex formation by human cytomegalovirus glycoproteins M (gpUL100) and N (gpUL73)," Journal of Virology, vol. 74, no. 24, pp. 1188111892, 2000.

[49] S. X. Wu, X. P. Zhu, and G. J. Letchworth, "Bovine herpesvirus 1 glycoprotein $\mathrm{M}$ forms a disulfide-linked heterodimer with the U(L)49.5 Protein," Journal of Virology, vol. 72, no. 4, pp. 30293036, 1998.

[50] H. Y. Mchamstien, M. Mchamstien, and B. J. Yeung, "Herpes simplex virus tegument protein V1 elucidation and formation around the nucleocapsid," Journal of Virology, vol. 28, no. 2, pp. 1262-1274, 2007.

[51] M. Mallikrjun Kurjogi, R. Danappa Sanakal, and B. Basaveneppa Kaliwal, "Identification and analysis of putative promoter motifs in bovine herpes virus," Bioinformation, vol. 8, no. 23, pp. 1167-1170, 2012. 

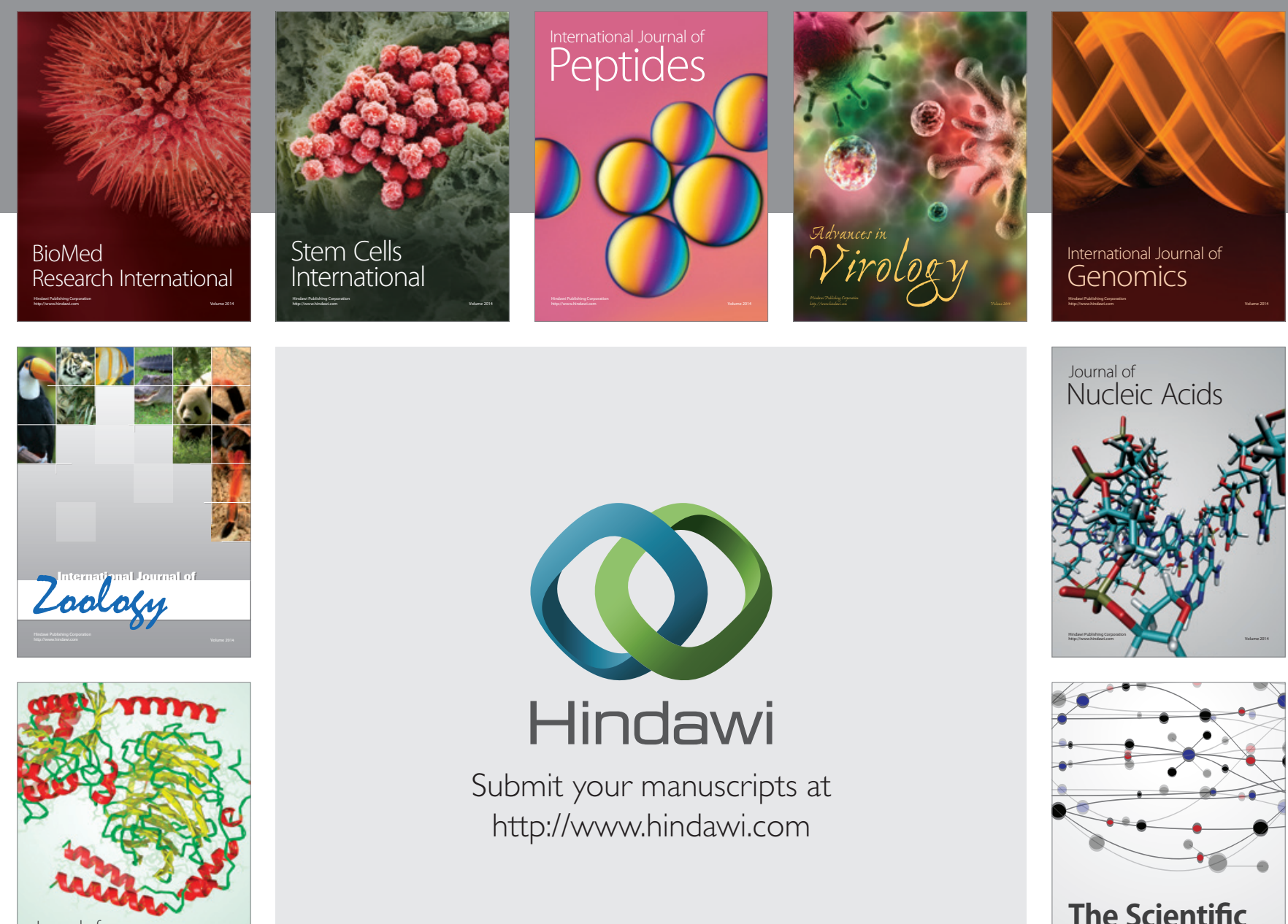

Submit your manuscripts at

http://www.hindawi.com

Journal of
Signal Transduction
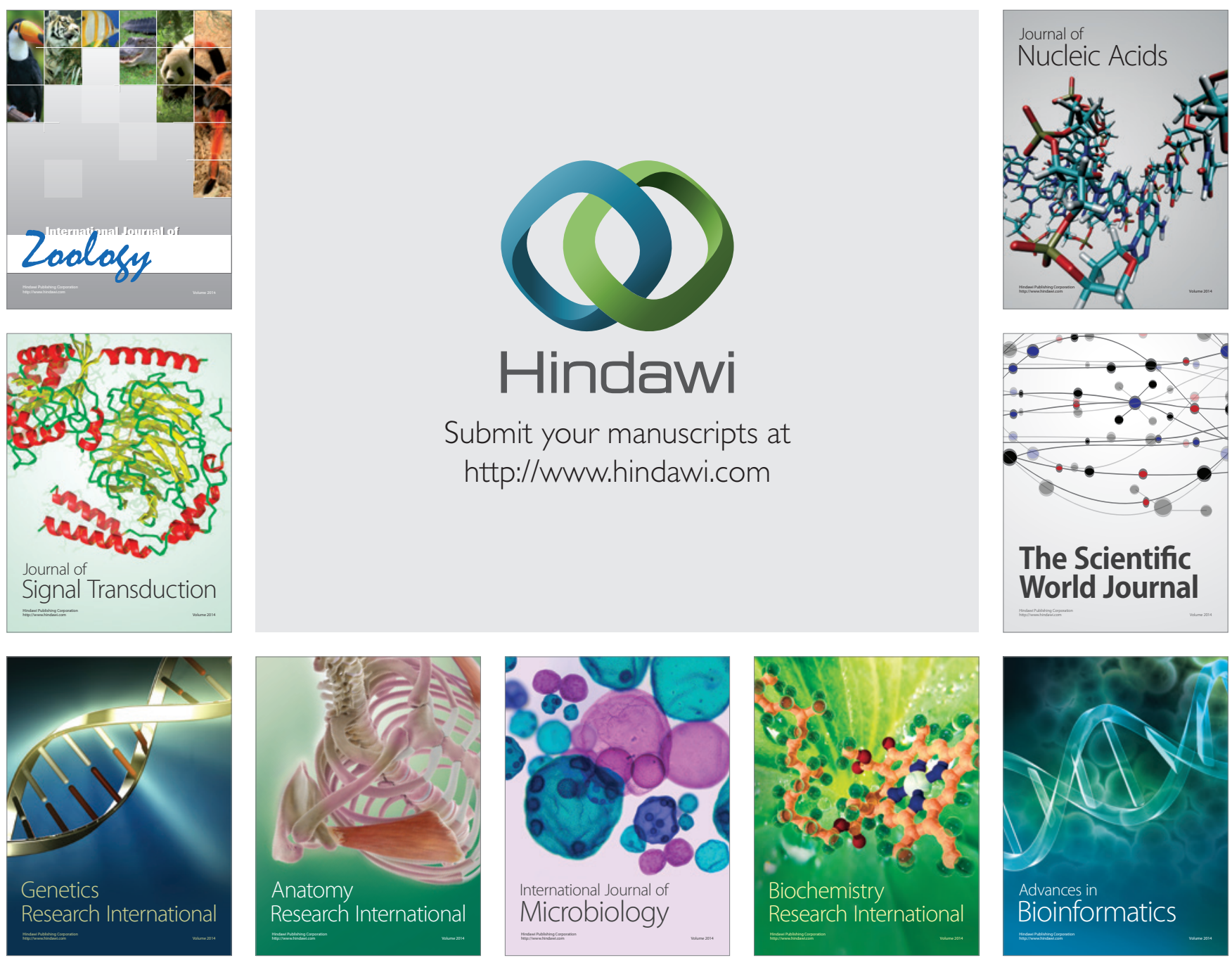

The Scientific World Journal
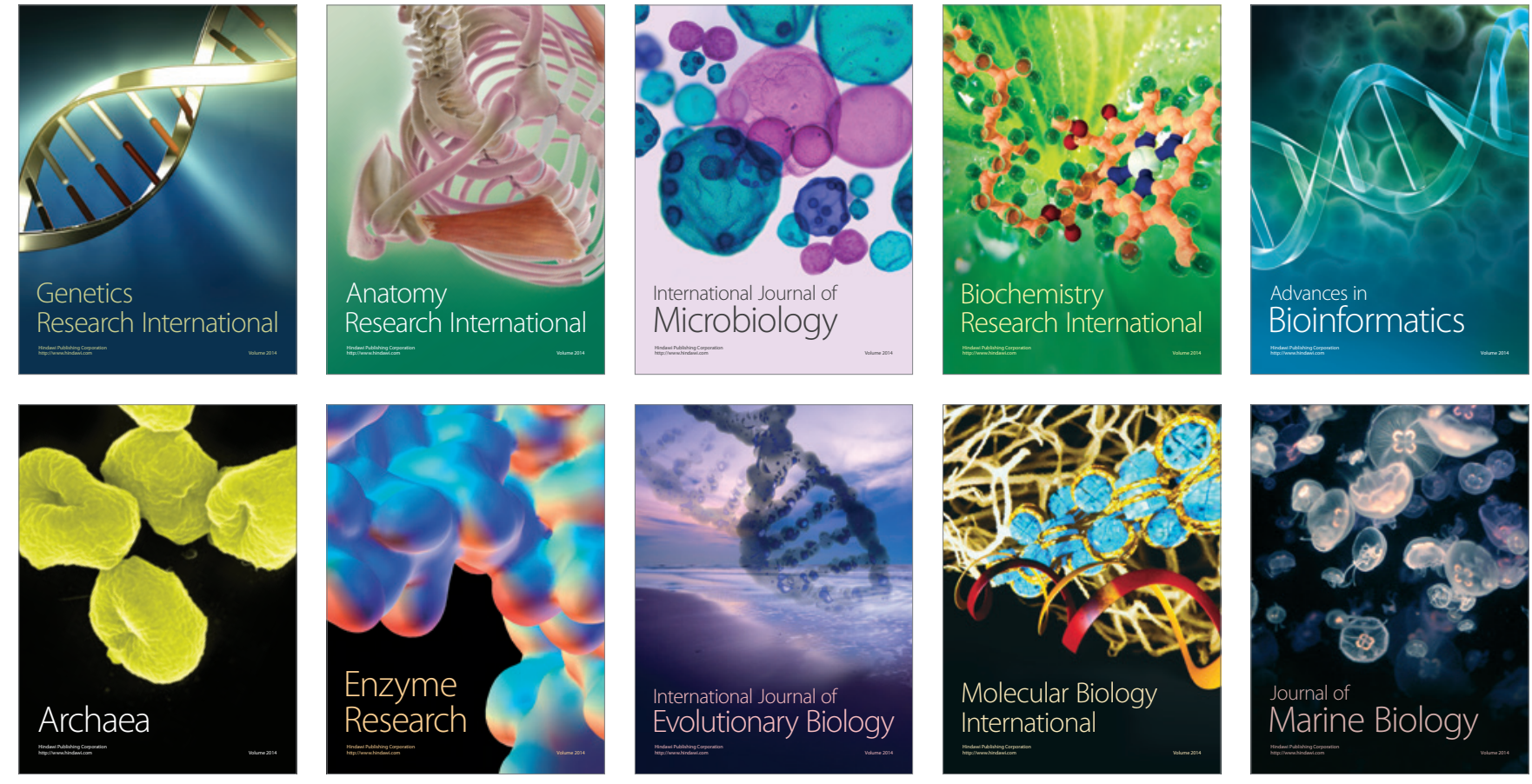